\title{
Correction to: The acrid raphides in tuberous root of Pinellia ternata have lipophilic character and are specifically denatured by ginger extract
}

\author{
Tsukasa Fueki ${ }^{1,2,3} \cdot$ Koichiro Tanaka $^{2} \cdot$ Kunihiko Obara $^{2,4} \cdot$ Ryudo Kawahara $^{2,5} \cdot$ Takao Namiki $^{6} \cdot$ Toshiaki Makino $^{3}$
}

Published online: 6 March 2021

(c) The Author(s) 2021

\section{Correction to: \\ Journal of Natural Medicines (2020) 74:722-731 \\ https://doi.org/10.1007/s11418-020-01425-6}

The article The acrid raphides in tuberous root of Pinellia ternata have lipophilic character and are specifically denatured by ginger extract, written by Tsukasa Fueki, Koichiro Tanaka, Kunihiko Obara, Ryudo Kawahara, Takao Namiki and Toshiaki Makino, was originally published Online First without Open Access. After publication in volume 74 , issue 4 , page 722-731 the author decided to opt for Open Choice and to make the article an Open Access publication. Therefore, the copyright of the article has been changed to (C) The Author(s) 2021 and the article is forthwith distributed under the terms of the Creative Commons Attribution 4.0 International License (https://creativeco mmons.org/licenses/by/4.0/), which permits use, sharing, adaptation, distribution and reproduction in any medium or format, as long as you give appropriate credit to the original author(s) and the source, provide a link to the Creative Commons license, and indicate if changes were made.

The original article has been updated.

Open Access This article is licensed under a Creative Commons Attribution 4.0 International License, which permits use, sharing, adaptation, distribution and reproduction in any medium or format, as long as you give appropriate credit to the original author(s) and the source, provide a link to the Creative Commons licence, and indicate if changes were made. The images or other third party material in this article are included in the article's Creative Commons licence, unless indicated otherwise in a credit line to the material. If material is not included in the article's Creative Commons licence and your intended use is not permitted by statutory regulation or exceeds the permitted use, you will need to obtain permission directly from the copyright holder. To view a copy of this licence, visit http://creativecommons.org/licenses/by/4.0/.

Publisher's Note Springer Nature remains neutral with regard to jurisdictional claims in published maps and institutional affiliations.

The original article can be found online at https://doi.org/10.1007/ s11418-020-01425-6.

\author{
Toshiaki Makino \\ makino@phar.nagoya-cu.ac.jp \\ Matsuya Pharmacy, Niigata, Japan \\ 2 Department of Traditional Medicine, Toho University School \\ of Medicine, Tokyo, Japan \\ 3 Department of Pharmacognosy, Graduate School \\ of Pharmaceutical Sciences, Nagoya City University, \\ Nagoya, Japan \\ 4 Obara Coloproctology Clinic, Tokyo, Japan \\ 5 Department of Cardiology, Tokyo Nishi Tokushukai \\ Hospital, Tokyo, Japan \\ 6 Department of Japanese-Oriental (Kampo) Medicine, \\ Graduate School of Medicine, Chiba University, Chiba, Japan
}

